\title{
PENGARUH SENAM HAMIL TERHADAP NYERI PUNGgUNG PADA IBU HAMIL TRIMESTER II DAN III
}

\author{
Supriatin*Siti Aminah**
}

\begin{abstract}
ABSTRAK
Selama kehamilan seorang ibu akan mengalami berbagai perubahan-perubahan baik anatomis maupun fisiologis. Upaya yang dilakukan untuk mengurangi nyeri punggung dengan senam hamil merupakan salah satu kegiatan dalam pelayanan selama kehamilan atau prenatal care yang bertujuan untuk mempersiapkan dan melatih otot-otot sehingga dapat dimanfaatkan secara optimal. Penelitian ini bertujuan untuk mengetahui pengaruh senam hamil terhadap nyeri punggung pada ibu hamil trimester II dan III di puskesmas mundu desa setupatok Kabupaten Cirebon tahun 2017.

Jenis penelitian adalah penelitian quasi experiment dengan rancangan one group pre-test post-test. Populasi dalam penelitian ini adalah semua ibu hamil trimester II dan III di Puskesmas Mundu Desa Setupatok Kabupaten Cirebon pada periode bulan Januari-Februari 2017 yang berjumlah 38 orang dan pengambilan sampel menggunakan metode purposive sampling yaitu 22 orang. Pengambilan data menggunakan lembar instrument, penelitian skala numerik atau The Pain Numerical Rating Scale (PNRS). Analisa data yang digunakan adalah analisa univariat dan bivariat.

Hasil penelitian ini menunjukan bahwa dari hasil pre-test didapatkan hasil bahwa sebagian besar dengan intensitas nyeri sedang yaitu 13 orang $(59,1 \%)$. Hasil post-test didapatkan hasil bahwa sebagian besar dengan intensitas nyeri ringan yaitu 14 orang $(63,6 \%)$. Berdasarkan analisa statistik didapatkan perbedaan rata-rata intensitas nyeri pada ibu hamil trimester II dan III sebelum senam hamil sebesar 5,77 dan sesudah penyuluhan sebesar 3,05 dengan $t_{\text {hitung }}(10,304)>t_{\text {table }}(2,080)$ serta nilai probabilitas $(p=0,000)$, maka Ho ditolak dan artinya senam hamil efektif dalam menurunkan intensitas nyeri punggung pada ibu hamil trimester II dan III.
\end{abstract}

Kata kunci : Senam hamil, nyeri punggung, ibu hamil

\begin{abstract}
During pregnancy a mother will undergo various changes both anatomical and physiological efforts are being made to reduce back pain in pregnancy exercise is one of the activities in the ministry during pregnancy or prenatal care, which aims to prepare and train the muscles so that they can be optimally used. This study aims to determine the effect of pregnancy exercise back pain in pregnant women trimester II and III in the clinic mundu Setupatok village Cirebon regency in 2017.

This type of research is quasi-experimental research design with one group pre-test post-test. The population in this study were all pregnant women in the third trimester II and Setupatok Village Puskesmas Mundu Cirebon in the period January-February 2017 amounted to 38 people and sampling using purposive sampling method 22. Retrieving data using a numerical scale research instrument sheet or Namerical The Pain Rating Scale (PNRs. Analysis of the data used are univariate and bivariate.

This study shows that the results of the pretest showed that most of the pain intensity interval that is 13 people $(59.1 \%)$. The results of the post-test showed that most of the mild pain intensity, that is 14 people $(63.6 \%)$. Based on statistical analysis found differences in average pain intensity in pregnant women second and third trimester before pregnancy exercise at 5.77 and after counseling at 3.05 with the $t(10.304)>t$ table $(2.080)$ an the probability value ( $\mathrm{p} 0.000$ ), then Ho rejected and meaning pregnancy exercise effective in reducing the intensity of back pain in pregnant women trimester II and III.
\end{abstract}

Keywords :

\footnotetext{
* Staf Pengajar PSIK STIKes Cirebon

**Mahasiswa PSIK STIKes Cirebon
} 


\section{PENDAHULUAN}

Setiap wanita dikodratkan akan menjadi seorang ibu dimana pada wanita akan mengalami masa kehamilan yang merupakan suatu proses alami dan normal pada setiap wanita yang akan memiliki bayi dimana perlu proses yang di awali dengan fertilisasi atau penyatuan dari spermatozoa dan ovum dan dilanjutkan dengan nidasi atau implantasi. Bila dihitung dari saat fertilisasi hingga lahirnya bayi, kehamilan normal akan berlangsung dalam waktu 40 minggu atau 10 bulan atau 9 bulan menurut kalender internasional. ${ }^{1}$

Selama hamil seorang ibu mengalami banyak perubahan-perubahan yang terjadi perubahan ini tidak hanya berhubungan dengan bentuk dan berat badan, tetapi juga terjadi perubahan biokimia, fisiologis, bahkan psikologis yang merupakan konsekuensi dari pertumbuhan janin di dalam rahim. Perubahan ini sebenarnya bertujuan untuk menjaga metabolisme tubuh, mendukung pertumbuhan janin, serta persiapan persalinan dan menyusui dengan tingkatan yang bervariasi disetiap trimesternya. Selain itu proses kehamilan akan menimbulkan berbagai perubahan pada seluruh sistem tubuh, perubahan ini berdampak pada sistem kardiovaskuler, sistem pernafasan, sistem hormonal, sistem gastrointestinal, maupun sistem muskuloskeletal. $^{2}$

Perubahan fisik tersebut ditandai dengan adanya beban perut yang meningkat dan bertambah besar, hal ini mengakibatkan ibu merasa sulit bergerak dan mencapai posisi yang nyaman. Ibu hamil mencondongkan perut sehingga menambah lekungan pada bagian bawah punggung yang mengakibatkan pada daerah tersebut ibu merasakan nyeri. ${ }^{2}$ Faktor predisposisi nyeri punggung meliputi pertumbuhan uterus yang menyebabkan perubahan postur, penambahan berat badan, pengaruh hormon relaksin terhadap ligamen, riwayat nyeri punggung terdahulu, paritas dan aktivitas. ${ }^{3}$

Nyeri punggung ini biasanya akan meningkat intensitasnya seiring bertambahnya usia kehamilan karena nyeri ini merupakan akibat pergesekan pusat gravitasi waanita dan postur tubuhnya. Perubahan ini disebabkan oleh berat uterus yang membesar, membungkuk yang berlebihan, berjalan tanpa istirahat, dan angka beban. ${ }^{3}$ Menurut hasil penelitian epidemiologi yang terbatas yang dilakukan oleh Mayer, dkk nyeri punggung sering di perparah dengan terjadinya backache atau sering disebut dengan "nyeri pungung yang lama". Backache iniditemukan pada $45 \%$ wanita saat dicatat kehamilannya, meningkat $69 \%$ pada minggu ke-28 dan hampir bertahan pada tingkat tersebut. ${ }^{2}$

Keluhan rasa nyeri punggung yang dialami ibu hamil tidak bisa dianggap biasa. Jika nyeri punggung tidak segera diatasi, ini bisa mengakibatkan nyeri punggung jangka panjang, meningkatkan kecenderungan nyeri punggung pascapartum dan nyeri punggung kronis yang akan lebih sulit untuk diobati atau disembuhkan. ${ }^{3}$

Upaya yang dapat dilakukan oleh tenaga kesehatan adalah memberikan pendidikan kesehatan tentang pencegahan atau penanganan nyeri punggung pada ibu yaitu salah satu caranya dengan adanya senam hamil. Tujuan penelitian itu adalah untuk mengetahui pengaruh senam hamil terhadap nyeri punggung pada ibu hamil trimester II dan III di Desa Setupatok UPT Puskesmas Mundu Kabupaten Cirebon.

\section{METODE PENELITIAN}

Rancangan penelitian ini menggunakan rancangan one group pretest-protest design yakni desain eksperimen yang dilakukan dengan pretes sebelum perlakuan diberikan dan post tes sesudahnya, tanpa kelompok pembanding. Populasi dalam penelitian ini adalah ibu hamil trimester II dan III yang ada di Desa Setupatok UPT Puskesmas Mundu yaitu terdapat 22 ibu hamil. Sampel dalam penelitian ini adalah semua ibu hamil trimester II dan III yang ada di Desa Setupatok Kabupaten Cirebon, yang melakukan senam hamil dengan kriteria inklusi a) Ibu hamil trimester II (13-27 minggu) dan III (28 - 37 minggu) yang bersedia menjadi responden. b) Responden yang tidak memiliki riwayat buruk tentang kehamilannya. c) 
Responden yang mengalami keluhan nyeri punggung yang belum pernah mendapatkan senam hamil.

\section{HASIL PENELITIAN}

Distribusi Frekuensi Intensitas Nyeri Punggung Pada Ibu Hamil Trimester II Dan III Sebelum Dilakukan Senam Hamil

Tabel 1. Distribusi Frekuensi Intensitas Nyeri Punggung Pada Ibu Hamil Trimester II Dan III Sebelum Dilakukan Senam Hamil

\begin{tabular}{lcc}
\hline Intensitas Nyeri & Frekuensi & Persentase $(\%)$ \\
\hline Tidak ada & 0 & 0 \\
Ringan & 2 & 9.1 \\
Sedang & 13 & 59.1 \\
Berat & 7 & 31.8 \\
\hline Total & 22 & 100 \\
\hline
\end{tabular}

Berdasarkan tabel 1, terlihat bahwa intensitas nyeri punggung pada ibu hamil trimester II dan III sebelum dilakukan senam hamil sebagian besar responden dengan intensitas nyeri sedang yaitu 13 orang (59.1\%).

\section{Distribusi Frekuensi Intensitas Nyeri Punggung Pada Ibu Hamil Trimester II Dan III Sesudah Dilakukan Senam Hamil}

Tabel 2. Distribusi Frekuensi Intensitas Nyeri punggung Pada ibu hamil trimester II dan III Sesudah Dilakukan senam hamil

\begin{tabular}{lcc}
\hline \multicolumn{1}{c}{ Intensitas Nyeri } & Frekuensi & Persentase (\%) \\
\hline Tidak ada & 0 & 0 \\
Ringan & 14 & 63.6 \\
Sedang & 8 & 36.4 \\
Berat & 0 & 0 \\
\hline Total & 22 & 100 \\
\hline
\end{tabular}

Berdasarkan tabel 2, terlihat bahwa intensitas nyeri punggung pada ibu hamil trimester II dan III sesudah dilakukan senam hamil sebagian besar responden dengan intensitas nyeri ringan yaitu 14 orang $(63.6 \%)$.

\section{Analisis Pengaruh Senam Hamil Terhadap Nyeri Punggung Pada Ibu Hamil Trimester II Dan III}

Tabel 3. Pengaruh senam hamil terhadap nyeri punggung pada ibu hamil trimester II dan III

\begin{tabular}{lccc}
\hline Nyeri Punggung & Mean & Standar Deviasi & P value \\
\hline Sebelum & 5,77 & 1,660 & 0,000 \\
Sesudah & 3,05 & 1,214 & \\
\hline
\end{tabular}

Berdasarkan tabel 3 dapat dilihat rata-rata perbedaan nyeri punggung pretest dan post test adalah 2,727. Hal tersebut menunjukan bahwa ada perbedaan bermakna pada nyeri punggung ibu hamil trimester II dan III sebelum dan sesudah dilakukan senam hamil. Hal ini dapat dilihat dari uji $\mathrm{t}$ diperoleh nilai t sebesar 10,304 dan nilai probabilitas (sig) korelasi antara nyeri punggung pada ibu hamil trimester II dan III sebelum dan sesudah dilakukan senam hamil sebesar $0.000<0,05$ menunjukan hubungan yang signifikan. Perhitungan 
dengan menggunakan uji 2 sisi, dimana angka probabilitas $/ 2<0,025$. Angka probabilitas $0,000<0,025$ yang mengindikasikan bahwa $\mathrm{H}_{0}$ ditolak atau ada pengaruh senam hamil terhadap nyeri punggung pada ibu hamil trimester II dan III

\section{PEMBAHASAN \\ Intensitas Nyeri Punggung Pada Ibu Hamil Trimester II Dan III Sebelum Dilakukan Senam Hamil}

Berdasarkan hasil penelitian ini intensitas nyeri punggung pada ibu hamil trimester II dan III seperti pada tabel 1 dapat diketahui bahwa, intensitas nyeri punggung pada ibu hamil trimester II dan III sebelum dilakukan senam hamil adalah intensitas nyeri sedang sebanyak 13 orang $(59.1 \%)$.

Selama hamil nyeri punggung dapat dialami ibu hamil, ini merupakan hal yang fisiologis yang bisa saja terjadi pada trimester tertentu selama periode kehamilan. Ibu yang merasakan nyeri punggung biasanya ditandai dengan gejala utama yaitu nyeri atau perasaan lain yang tidak enak di daerah tulang punggung. ${ }^{1}$

Usia kehamilan merupakan faktor yang mempengaruhi nyeri punggung. Lebih dari sebagian ibu hamil usia kehamilan 4-6 bulan. Hal ini sesuai dengan pernyataan Varney 2006, bahwa nyeri punggung akan meningkat intensitasnya seiring pertumbuhan uterus yang sejalan dengan pertambahan usia kehamilan sehingga mengakibatkan teregangnya ligamen penopang, pergeseran pusat gravitasi dan postur tubuh semakin lordosis. Hal inilah yang biasanya dirasakan ibu sebagai spasme menusuk yang sangat nyeri yang disebut dengan nyeri punggung. ${ }^{3}$

Rasa nyeri merupakan stresor yang dapat menimbulkan stress dan ketegangan dimana individu dapat berespon secara biologis dan perilaku yang menimbulkan respon fisik dan psikis. Respon fisik meliputi perubahan keadaan umum, tulang belakang, denyut nadi, pernafasan, suhu badan, sikap tubuh, dan apabila nafas makin berat apabila nafas makin berat dapat menyebabkan kolaps kardiovaskuler dan syok, sedangkan respon psikis akibat nyeri dapat merangsang respon stress yang dapat mengurangi sistem imun dalam peradangan.

Perawat dengan pengetahuan dan keterampilannya dapat mengatasi masalah nyeri punggung yang sering dialami ibu hamil trimester II dan III, baik secara mandiri maupun kolaboratif. Ada dua pendekatan yang digunakan untuk mengatasi gangguan nyeri punggung, yaitu pendekatan farmakologi dan non farmakologi. Pendekatan farmakologi merupakan tindakan pendekatan dengan pemberian obat yang mampu untuk mengatasi masalah nyeri punggung. Sedangkan non farmakologi, merupakan tindakan dengan menggunakan teknik seperti relaksasi.

Terapi non farmakologi yang sering digunakan untuk mengurangi gangguan nyeri punggung pada ibu hamil trimester II dan III adalah dengan dilakukannya senam hamil. Senam hamil merupakan cara yang mendukung kemudahan dalam persalinan dan membantu memberikan relaksasi terhadap kehamilan trimester III. Senam hamil bertujuan mempersiapkan dan melatih otot-otot sehingga dapat berfungsi secara optimal dalam persalinan normal. Senam dapat mengurangi berbagai gangguan yang umumnya terjadi selama kehamilan seperti varises, sakit pinggang serta nyeri otot dan persendian, meningkatkan stamina yang sangat diperlukan selama persalinan dan menguatkan serta mengencangkan otot yang paling banyak mempengaruhi dalam kehamilan: otot pelvis, otot perut dan otot punggang. ${ }^{2}$

Berdasarkan uraian di atas peneliti berpendapat bahwa nyeri punggung pada ibu hamil dapat dipengaruhi oleh usia kehamilan dan kenaikan berat badan pada saat kehamilan semakin membesar sehingga menyebabkan perubahan postur tubuh yang berlebihan dan gravitasi tubuh bergeser kedepan yang mengakibatkan otot sekitar pelvis tidak seimbang, 
menyebabkan terjadinya nyeri punggung dengan skala nyeri sedang yang mengganggu ibu hamil dalam aktivitas.

Oleh karena itu, penjadwalan tempat dan waktu senam hamil harus terjadwal, baik dari puskesmas maupun tempat lingkungan sekitar ibu hamil sehingga efek kesehatan yang optimal lebih baik pada ibu hamil trimester II dan III.

\section{Intensitas Nyeri Punggung Pada Ibu Hamil Trimester II Dan III Sesudah Dilakukan Senam Hamil}

Berdasarkan hasil penelitian ini intensitas nyeri pada pasien fraktur seperti pada tabel 2 dapat diketahui bahwa, intensitas nyeri pada pasien fraktur sesudah dilakukan senam hamil adalah intensitas nyeri ringan sebanyak 14 orang $(63,6 \%)$. Nyeri punggung mungkin terjadi disebabkan oleh regangan otot yang tidak berbahaya, masalah struktural yang signifikan seperti prolaps diskus atau kolaps vertebral, atau yang lebih jarang, sebagai keluhan atas penyakit keganasan seperti mieloma atau metastasis ke tulang, atau kelainan intra abdomen seperti aneurisma aorta atau pankreatitis. ${ }^{5}$

Senam hamil adalah latihan jasmani yang bertujuan membuat elastis otot dan ligament yang ada di panggul, memperbaiki sikap tubuh, mengatur kontraksi dan relaksasi, serta mengatur teknik pernapasan. ${ }^{1}$

Senam hamil dapat meringankan keluhan nyeri punggung yang dirasakan oleh ibu hamil karena didalam senam hamil terdapat gerakan yang dapat memperkuat otot abdomen. Fungsi penting dari otot abdomen yaitu kontrol pelvis saat menengadah. Ketika ligamen di sekitar pelvis menegang dan tidak lagi memberikan topangan yang kuat kepada sendi maka otot menjadi garis pertahanan kedua membantu mencegah tegangan yang berlebihan pada ligamen pelvis. Harus diingat bahwa tegangan yang berlebihan pada pelvis dan melemahnya otot abdomen inilah yang menyebabkan nyeri punggung. Untuk itu perlu dilakukan latihan ini untuk mempertahankan tonus otot abdomen yang baik. Menurut Emilia dan Freitag, selain itu pada saat melakukan senam hamil tubuh akan memproduksi endorfin lebih banyak. Endorfin dikenal sebagai zat yang memiliki prinsip kerja seperti morfin yang berfungsi untuk memberikan ketenangan, mengatasi stress pada saat hamil dan mampu untuk mengurangi nyeri seperti nyeri pada daerah punggung.

Berdasarkan hasil penelitian dapat disimpulkan bahwa senam hamil dapat menurunkan gangguan nyeri punggung pada ibu hamil trimester II dan III karena telah dilakukan senam hamil yang dapat memberikan pengaruh yang baik bagi ibu hamil trimester II dan III dengan gangguan nyeri punggung, dimana ibu hamil trimester II dan III dibimbing untuk sangat rileks, dan dalam kondisi tubuh yang sehat tidak memiliki riwayat penyakit gawat kemudian diberikan intruksi sebelum melakukan senam hamil sehingga dapat mengubah persepsi pada ibu hamil trimester II dan III.

\section{Pengaruh Senam Hamil Terhadap Nyeri Punggung Pada Ibu Hamil Trimester II Dan III}

Pengujian dengan menggunakan paired sample test diperoleh rata-rata nyeri punggung pada ibu hamil trimester II dan III sebelum (pre test) dilakukan senam hamil sebesar 5,77 ( $\mathrm{SD}=1,660)$, dan sesudah (post test) dilakukan senam hamil sebesar 3,05 ( $\mathrm{SD}=1,214)$ dengan $\mathrm{t}$ hitung $10,304>\mathrm{t}$ table 2,080. Perhitungan dengan menggunakan uji 2 sisi, dimana angka probabilitas $/ 2<0,025$. Angka probabilitas $0,000<0,025$ yang mengindikasikan bahwa $\mathrm{H}_{0}$ ditolak atau ada pengaruh senam hamil terhadap nyeri punggung pada ibu hamil trimester II dan III di Desa Setupatok UPT Puskesmas Mundu Kabupaten Cirebon Tahun 2017.

Hal ini menunjukan bahwa ada pengaruh senam hamil terhadap nyeri punggung dimana sebelum (pre test) dilakukan senam hamil sebesar 5,77 ( $\mathrm{SD}=1,660)$, dan sesudah (post test) dilakukan senam hamil sebesar 3,05 $(\mathrm{SD}=1,214)$ 
Senam hamil adalah latihan fisik berupa beberapa gerakan tertentu yang dilakukan khusus untuk meningkatkan kesehatan ibu hamil. Yang mana senam hamil dilakukan dengan tujuan membuat elastis otot dan ligamen yang ada di panggul, memperbaiki sikap tubuh mengatur kontraksi dan relaksasi serta mengatur teknik pernapasan.

Dengan melakukan senam hamil secara teratur dipercayai dapat menurunkan nyeri punggung, salah satunya dengan latihan transversus, latihan dasar pelvis dan peregangan umumnya pada ibu hamil. $^{2}$

Oleh karena itu latihan senam hamil perlu diajarkan pada masa antenatal untuk memastikan kembalinya bentuk otot ke bentuk normal pascanatal dengan cepat, kemampuan mengejan yang efektif saat persalinan, terutama mengurangi nyeri punggung selama kehamilan.

Berdasarkan hasil penelitian berpendapat bahwa pada pengukuran sebelum dan sesudah dilakukan senam hamil pada intensitas nyeri punggung mengalami penurunan, dimana diperoleh intensitas nyeri dari sedang menjadi ringan. Disarankan kepada instansi terkait agar dapat mensosialisasikan tindakan senam hamil kepada ibu hamil khususnya ibu hamil dengan keluhan nyeri punggung pada trimester II dan III tentang manfaat senam hamil untuk mencegah keluhan nyeri punggung.

Perlunya tindak lanjut dalam peningkatan pemberian informasi dan motivasi dengan memberikan penyuluhan tentang manfaat senam hamil, gerakan senam hamil yang baik dan benar pada saat ibu hamil.

\section{KESIMPULAN}

1. Hasil sebelum dilakukan senam hamil didapatkan hasil bahwa intensitas nyeri punggung pada ibu hamil trimester II dan III adalah nyeri punggung sedang yaitu 13 orang $(59,1 \%)$.

2. Hasil setelah dilakukan senam hamil didapatkan hasil bahwa intensitas nyeri punggung pada ibu hamil trimester II dan III adalah nyeri punggung ringan yaitu 14 orang $(63,6 \%)$.

3. Terdapat perbedaan rata-rata intensitas nyeri punggung pada ibu hamil trimester II dan III sebelum dilakukan senam hamil sebesar 5,77 dan sesudah dilakukan senam hamil sebesar 3,05 dengan $t_{\text {hitung }} 10,304>t$ table 2,080 serta nilai probabilitas 0,000 maka Ho ditolak dan artinya ada pengaruh senam hamil terhadap nyeri punggung pada ibu hamil trimester II dan III.

\section{SARAN}

\section{Bagi Ibu hamil}

Hasil penelitian ini diharapkan dapat membantu ibu hamil untuk mengetahui gangguan nyeri punggung yang dialami sehingga dapat memperlancar aktivitas sehari-hari dan diharapkan ibu hamil bisa melakukan senam hamil sesuai dengan intruksi oleh bidan. Khususnya apabila ibu hamil mengalami rasa tindak nyaman nyeri, dalam penanganan untuk menurunkan rasa nyerinya. Sesuai dalam buku panduan yang telah di berikan dan diajarkan oleh bidan / tenaga kesehatan lainnya supaya dapat meringankan keluhan nyeri punggung yang dialami dengan dilakukan senam hamil dan harus didampingi oleh ahlinya.

2. Bagi Instansi Penelitian

Hasil penelitian ini diharapkan dapat menjadi bahan masukan untuk puskesmas mundu kabupaten cirebon, dalam menyusun Standar Operasional Prosedur (SPO) penatalaksanaan nyeri punggung non farmakologis dengan dilakukan senam hamil dalam intervensi mandiri keperawatan.

3. Bagi Program Studi Ilmu Keperawatan Stikes Cirebon

Hasil penelitian ini diharapkan dapat dijadikan bahan referensi untuk perpustakaan dan sebagai dasar bagi penelitian selanjutnya tentang pengaruh senam hamil terhadap nyeri punggung pada ibu hamil trimester II dan III. 


\section{Peneliti Selanjutnya}

Hasil penelitian ini diharapkan dapat dijadikan acuan untuk peneliti yang dilakukan pada ibu hamil berbeda mengenai metode terapi non farmakologis terhadap intensitas nyeri punggung pada ibu hamil trimester II dan III untuk lebih mendukung dan memperkuat hasil penelitian.

\section{DAFTAR PUSTAKA}

1. Nur Aini Rahmawati, Titin Rosyidah, Andrya Marhani. Hubungan Pelaksanaan Senam Hamil Dengan Ketidaknyamanan Ibu Hamil Trimester III Di Bidan Praktek Mandiri Supadmi, Kunden Bulu, Dukoharjo.Jurnal Involusi Kebidanan. 2016; Vol 7. No 12

2. Febrina Yosefa, Misrawati, Yesi Hasneli. Efektifitas Senam Hamil Terhadap Penurunan Nyeri Punggung Pada Ibu Hamil. Jurnal infokes. 2015: vol 5. No 1

3. Isma'ul Lichayati, Ratih Indah Kartika. Hubungan Senam Hamil Dengan Nyeri Punggung Pada Ibu Hamil Di Polindes Desa Tlanak Kecamatan Kedungpring Kabupaten Lamongan. Jurnal Surya. 2013; Vol 1.No14

4. Jonathan Gleadle. Anamnesis Dan Pemeriksaan Fisik. Jakarta. Erlangga; 2005

5. Notoatmodjo, Soekidjo. Metodologi Penelitian Kesehatan. Jakarta: Rineka Cipta; 2012 